\title{
White-Winged Scoter Banding
}

\author{
By Dr. Stuart Houston
}

It is the unexpected that makes birding so much fun-and this was proved again on June 28 when S. R. Belcher, Margaret Belcher and myself went ashore on a little island at the north end of Last Mountain Lake. This particular island was less than an acre in size and had a fairly dense cover of nettles and rose bushes. Almost at once a heavy black female White-winged Scoter flushed from her nest and made for the water's edge in a lumbering fashion. Nearby another took to the air with wings fluttering heavily against the growth of nettles. We were impressed by the slowness of their getaway, and decided that perhaps we might have caught them if we had moved a little faster. Alerted for action, at the first sound of movement, the next Scoter was pounced upon before it could get away. The next four were similarly picked up, either running through the nettles or trying to fly. However, one emerged at the edge of the nettles and made an easy takeoff over a patch of low grass.

We had caught (and banded) five of the eight Scoters nesting on the little island, and really we could have had seven if we had been psychologically prepared to move faster at the first. We examined five of the nests-they contained 14, 12, 13,12 , and 12 eggs! After this excitement our enthusiasm ran high-and we laboriously combed all the nettle patches on a much larger island nearby. Only two more Scoters were flushed - one got away, the other was banded.

The White-winged Scoter is the heaviest of our prairie ducks and Bent remarks how its flight is "heavy and apparently labored-it seems to experience considerable difficulty in lifting its heavy body from the surface of the water." It is more common than usually imagined and a resident of most Saskatchewan lakes with a depth of five feet or more. However, they are rarely banded, and it was a real thrill to add this species to my banding total.

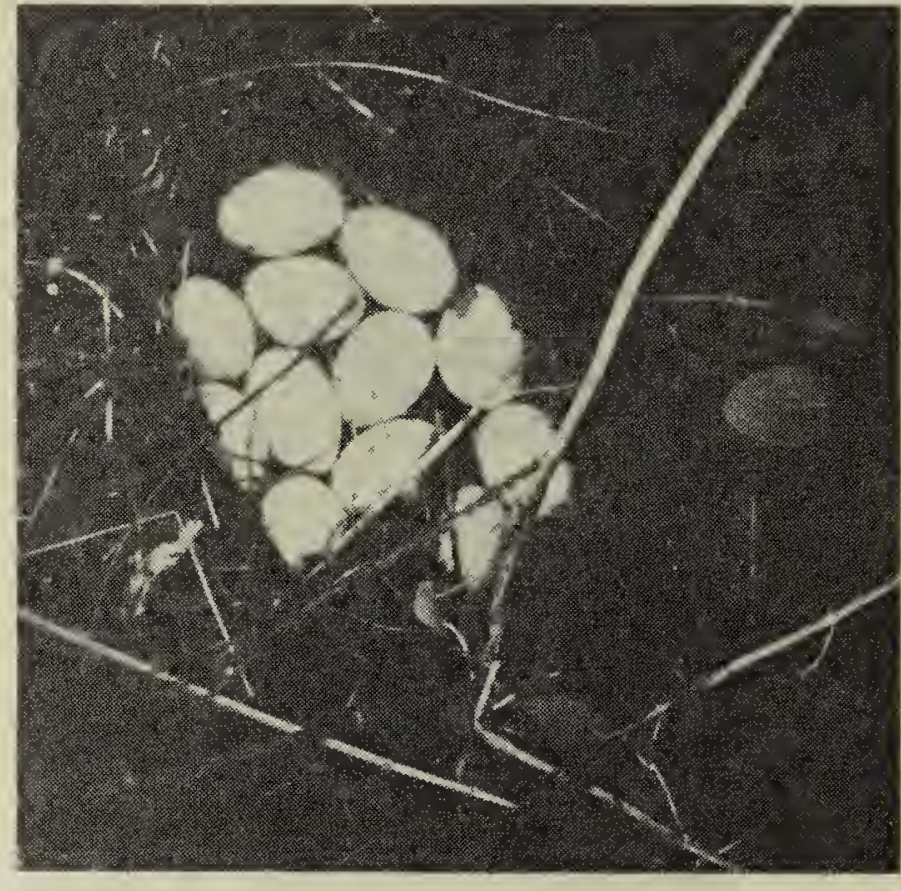

-Photo by Dr. Stuart Houston

\section{PERCHING HUMMINGBIRDS}

Mrs. Keith D. Paton, Oxbow, Sask.

Mrs. Marion Nixon, of Wauchope, wrote in one of her recent columns that she had only once seen a hummingbird perching. Several years ago I had the good fortune to observe a tiny green Hummingbird, not once, but several times, perching in various places around my flower garden. On several occassions he was just sitting on a maple branch preening himself. Once he was perched precariously on the wire in the sweet pea net wire.

I also watched with interest one day as the male chased the tiny female away from the hollylocks. I had read that they do this. Possibly they nested here that year, for usually we see them only once or twice during the summer. They were always green with light underparts, with no ruby-throat showing.

\section{THE PURPLE ASTER}

Along the path through the bush The pretty aster grows,

Amongst the red and yellow leaves Its purple beauty shows.

The fall has spread o'er the land And winter is not far away.

Thanks be to Nature for her gift

On this bright sunny day. - -Fred C. Meers, Winnipeg. 